\title{
Blended learning and team teaching: Adapting pedagogy in response to the changing digital tertiary environment
}

\author{
Renée Crawford \\ Faculty of Education, Monash University, Australia \\ Louise Jenkins \\ Faculty of Education, Monash University, Australia
}

\begin{abstract}
Increased accessibility of advanced technology, the targeted use of online learning platforms, student flexible learning expectations and the pressures of faculty budget constraints and priorities have called into question the effectiveness of traditional tertiary teaching and learning models. The tertiary education context must evolve at a pace consistent with the growing expectations and requirements of an innovative society. A teacher-led research project was devised to navigate through some of the complexities and implications associated with necessary pedagogical change in response to the transitioning digital tertiary environment. The development and implementation of blended learning and team teaching strategies were introduced into the pedagogy of a tertiary pre-service teacher education methods class. This paper reports on three sequential years of findings, which will explore student understandings of blended learning and team teaching and the overall impact they had on their learning in this context.
\end{abstract}

\section{Introduction}

The nature of teaching within the tertiary education system is gradually evolving due to the increased provision of accessible advanced technology, the targeted use of online learning platforms, student flexible learning expectations and the pressures of faculty budget constraints. The University Experience Survey (UES) was developed to provide a national architecture for collecting feedback on key facets of the higher education student experience and obtain data on the levels of engagement and satisfaction of current commencing and later-year undergraduate students. Statistics from the 2014 UES National Report revealed that across all courses, only 57\% of students were satisfied with the level of learner engagement received (UES Consortium, 2015). The category of learner engagement focuses on the degree of attention, curiosity and interest created while studying and links directly to student motivation factors. This calls into question current tertiary education practice and the effectiveness of traditional tertiary teaching and learning models. This is further exemplified by the 2015 Blended Learning conference that sought to address the decrease of Australian government funding for university development at a time when technology-savvy students are becoming more prevalent in lecture theatres across the country. Educational developers and academics are looking to different techniques in delivering information to students. Utilising digital and online resources, and changing pedagogy in order to incorporate these effectively into course design, has become key in increasing student engagement and, subsequently, achievement (Australian Council for Educational Research, 2009; Montgomery, Hayward, Dunn, Carbonaro, \& Amrhein, 2015).

In response to this priority area in the tertiary sector, a teacher-led research project was devised in 2012 to navigate through some of the complexities and implications associated with necessary pedagogical change in response to the transitioning digital tertiary environment. The authors, two practitioner researchers and lecturers in the pre-service teacher education secondary specialism in the Faculty of Education at Monash University, have developed an innovative pedagogical approach that uses a combination of blended learning and team teaching strategies. This paper considers some of the literature which underpins this study, the methodology, three cycles of data which corresponds with three sequential years of results and the future direction of the project. The results explore student understandings and experiences of blended learning and team teaching and the overall impact they had on their learning in this context. Drawing on the student perspective is valuable in considering implications for immediate and future pedagogical considerations in the tertiary context. As such, the primary data drawn on for the student perspective is two surveys (pre and post the unit taught) administered in each of the three years. While the student cohorts in each of these respective years are different, it is useful to think about this in terms of a time continuum where teaching is always slightly modified and adapted according to the needs and requirements of the particular student cohort at the time, but the overall blended learning and team teaching framework remains unchanged. 
Team teaching is not a new concept; however, blended learning has emerged between 1996 and 2016 in a significant way in response to technologically driven expectations that are changing education systems and paradigms. This project brings together these two elements in an exploration of the impact of the combination of blended learning and team teaching strategies within the tertiary environment.

Blended learning has already become an indispensable part of education practice in many disciplines and fields of study. Despite such an enthusiastic reception and a growing body of empirical research regarding blended and online learning, analyses of such approaches in disciplines within the social sciences and educational contexts remains limited (Arbaugh, Bangert, \& Cleveland-Innes, 2010; Ginns \& Ellis, 2009; Pektas \& Gürel, 2014). Further, much research on blended learning has assumed homogeneity of disciplines (Pektas \& Gürel, 2014). It would be naïve to suggest that each field of study would engage in teaching and learning in the same way. As such the characteristics discussed in this study are consonant with the initial pre-service teacher tertiary education context. While it is realised that an extensive review of literature would be beyond the scope of this paper, included are the studies that underpin this research.

\section{Blended learning}

Blended learning, also referred to as hybrid learning, is a combination of learning modalities involving face-to-face and web-based or online learning interaction, instruction and delivery. Proponents of blended learning advocate that incorporating asynchronous Internet communication technology into higher education courses serves to facilitate a simultaneous independent and collaborative learning experience (Garrison \& Kanuka, 2004). Robinson (2004) describes blended learning as an approach where a faculty member meets with their students face-to-face for regular scheduled classes, while students fulfil the course requirements by accessing learning materials online and participating in class discussions over the Internet within a secure website. The leveraging of technology and social networks is critical to the blended learning process (Rosenburg, 2006). It is reasonable to suggest that the social networking element of this approach appeals to the engagement of 'digital natives' (Prensky, 2001), the student cohort who make up a high percentage of current and future university classes. In comparison, Picciano (2006) suggests that blended learning is a substantial integration of technologies into on-site instruction. The Sloan Consortium investigated the nature and extent of blended education in the United States. They define blended learning as a course where the proportion of content delivered online is $30 \%$ to $79 \%$ (Sloan Consortium, 2007). While this is a useful guideline, it may not be sufficient to completely define an institution's blended program. While the definitions for blended learning are diverse and varied, there appears to be consensus that it involves a mix of traditional on-site instruction with innovative learning technologies (Gedik, Kiraz, \& Ozden, 2013; Osguthorpe \& Graham, 2003; Thorne, 2003).

A report published by the Department of Education and Early Childhood (DEECD) examined seven case studies that investigate the blended learning approach. The findings concluded that this method created a culture based on the acceptance of change and risk taking (DEECD, 2012). Students in these various educational contexts learned to independently and collaboratively overcome issues, problem-solve and challenge themselves. These examples of blended learning not only proved to have beneficial learning outcomes, but ranked highly on satisfaction ratings with both students and educators (DEECD, 2012). Further, it has been suggested that educational technologies have the potential to support the priorities and common goals of a university education, specifically in blended learning contexts (Mortera-Gutiérrez, 2006; Spiliotopoulos, 2011).

There is an increasing number of students who study online, but retention rates are highly problematic (Edwards \& McMilla, 2015; Hare, 2010; United Sates Department of Education, 2009; Xu \& Jaggers, 2011a, 2011b). Reports indicate that online retention rates in some United Sates universities are regularly 15\%-20\% lower than face-to-face classes (United States Department of Education, 2009). In a longitudinal five-year study involving more than 50,000 students, Xu and Jaggers (2011b) found that students were more likely to fail or withdraw from purely online courses in comparison to those which offered face-toface and or blended learning modes. This challenge of decreasing tertiary online retention rates is also prevalent in Australia (Edwards \& McMilla, 2015) and has reportedly cost Australian universities more than $\$ 1.4$ billion or an average of \$36 million per institution (Hare, 2010). This exemplifies not only the need in changing pedagogy and approach in such a context, but highlights the benefits of the blended and flexible approaches on learning, which have proven to be more successful than purely online course 
offerings (McCarthy, 2010; Montgomery et al., 2015; Oblender, 2002). University students expect flexible, innovative and engaging learning experiences with technologies that they commonly use or will be expected to use in today's professional, academic and social environments (Spiliotopoulos, 2011). Blended learning can respond to and support university goals and values, and in doing so, establish itself as an embedded part of courses and programs; but educators need to be willing to experiment and change their pedagogy accordingly.

It has been identified that innovative solutions through blended learning may be beneficial in responding to the issue of reduced government funding to Australian universities in an unpredictable time of required educational change. Such an approach will allow for an expansion of faculty, library and classroom facilities and a maximisation of resources through technology (Robinson, 2004). Less face-to-face teaching also means a reduction in the requirements to compete for brick-and-mortar classroom space and in turn less monitory outlay. Further, blended learning provides students with more flexibility to learn when, where and how they choose, while educators continue to guide their learning experiences. The approach also has the capacity to broaden learning opportunities in both independent and collaborative ways and enhance the application of knowledge than has previously been the case (DEECD, 2012; Garrison \& Kanuka, 2004; Robinson, 2004). A group of professors discovered that through blended learning students 'actively engaged with course materials and showed an improved grasp and understanding of course content' (American University of Beirut, 2010). One disadvantage of the approach is that it can be time consuming to implement. Extra time is required to redesign courses appropriately and the approach results in increased student email, the necessity to monitor discussion forums as well as interact in them and more teaching time overall (American University of Beirut, 2010; Picciano, 2006; Sloan Consortium, 2007). Despite these disadvantages, the education learning outcomes for students are significant. While there is a decrease in funding from an institutional or faculty perspective, there is an increase in cost in time and workload to the academics involved as will be discussed in the team teaching section.

Extensive academic research has proposed and discussed a number of blended learning design approaches (Boyle, Bradley, Chalk, Jones, \& Pickard, 2003; DEECD, 2012; Garrison \& Kanuka, 2004; Garrison \& Vaughan, 2011; Hoic-Bozic, Mornar, \& Boticki, 2009; Huang \& Zhou, 2005; McCarthy, 2010; MorteraGutiérrez, 2006; Newcombe, 2011; Sloan Consortium, 2007), with some identifying the benefits and challenges to many of these approaches. However, there has been little research on the consideration of changing pedagogy and the combination of team teaching strategies with blended learning in a tertiary education context.

\section{Team teaching}

The term team teaching is also referred to by education practitioners and researchers as 'cooperative teaching' (Bauwens \& Hourcade, 1997), ‘collaborative teaching’ or 'teacher collaboration’ (Boulay, 2005; Welch \& Sheridan, 1996) and 'co-teaching' (Friend \& Cook, 2007). There is general consensus that team teaching involves two or more people sharing responsibility of teaching some or all of the students assigned to a class (Fuller \& Bail, 2011). In the tertiary context, this may also include two or more academics working together teaching one course or 'planning several classes as cluster courses' (Letterman \& Dugan, 2004, p. 76). Team teaching is considered a collaborative teaching approach in which two or more teachers share the planning, curriculum and content development, delivery or presentation of teaching and learning materials and assessment (Boulay, 2005; Davis, 1995; Friend \& Cook, 2007; Letterman \& Dugan, 2004). It is in this context that team teaching is practised in this teacher-led research project.

Team teaching has received some enthusiastic analyses, but this has come with a particular pragmatism about the associated challenges. Early research identified issues such as staffing cuts, resource reductions, course changes and reluctance by staff to teach in front of others (Freeman, 1969). It was also found that pedagogical and logistical differences of opinion among teachers in the team may cause insurmountable friction, including curriculum and content disruption, the problematic management of larger student groups and the potential for academic careers to be jeopardised (Bess, 2000; Davis, 1995; Eisen, \& Tisdell, 2000; Geen, 1985). There is a number of aspects to consider when finding and cultivating a team of academics to work together in a highly functioning team teaching capacity. These include finding like-minded people and personalities, expertise, pedagogical philosophy, flexibility, mutual respect and the freedom to share opinions and ideas in a supportive environment (Eisen, 2000). These considerations are critical in developing an effective instructional connection to enable the provision of a variety of learning experiences 
and opportunities for students. Further, establishing aims and devising clearly defined procedures and strategies that are linked back to teaching and learning intensions are important to the success of team teaching (Arnold \& Jackson, 1996; Bondy \& Ross, 1998; George \& Davis-Wiley, 2000; Robinson \& Schaible, 1995; Vogler \& Long, 2003; Winn \& Messenheimer-Young, 1995). If the intention is merely to share the workload, then there may be no attempt to inquire into teaching or to collaborate (Benjamin, 2000). However, if the intention is to become involved in improving teaching and learning outcomes, then the strategy will work towards these goals and engage in scholarly teaching practice (Benjamin, 2000). The intention impacts on the strategy, which in turn impacts on the learning process for the students.

It is widely recognised that there are many benefits of team teaching, including the sharing of resources and materials, the ability for teachers to ask other specialists for advice and the increased sense of security that comes from the shared responsibility for the intellectual and emotional growth of students (Bess, 2000; Eisen, \& Tisdell, 2000; Farey, 1974). Team teaching enhances the professional development of the academics involved 'because of the opportunities it offers for collaborative reflection' (Knights \& Sampson, 1995, p. 58). This is particularly important in the tertiary environment, where it is common for academics to feel quite isolated at times. However, despite the clear benefits for academics, team teaching can involve more time and effort than a more traditional approach (Mansell, 2006). Unfortunately, at a time when universities budgetary cuts are impacting academics' workloads, this has implications for the practicality of the approach as academics may disregard it on this basis alone.

The literature suggests that students can benefit significantly from team teaching courses in the following ways: deepen students' analytical abilities; build greater curricular coherence; create a stronger sense of academic community; provide explicit structures for academic and social engagement; improve studentteacher relationships; make classes more interesting and challenging due to the depth and diversity of teacher experience drawn upon; improve retention rates, student learning outcomes, develop interpersonal and communication skills (Benjamin, 2000; Johnson, Johnson, \& Smith, 2000; Smith, 1994). It also allows for more immediate feedback to students (Fuller \& Bail, 2011; Haddon, 2011), both online and in the classroom. Significantly, tertiary team teaching may also support an increased focus on the learning instead of just accumulating knowledge (Shibley, 2006) leading to improved student engagement (Donnison, Edwards, Itter, Martin, \& Yager, 2009). The presence of two or more teachers provides a wider range of teaching ideas and pedagogy, which have a positive impact on students (Haddon, 2011). Further, team teaching can also enrich the experience of students, who may gain social and academic benefits 'through participation in the inclusive and collaborative instructional models’ (York-Barr, Ghere, \& Sommerness, 2007, p. 331). Depending on the team teaching approach utilised there are also collaborative opportunities that can be extended to the interplay between teachers and students. This includes student-centred learning approaches such as shared intellectual control, where students are part of some of the decision-making about their own learning (Eisen, \& Tisdell, 2000). In the approach taken in this research project, this is used to facilitate critical thinking and the development of students' ability to see themselves as constructors of knowledge in the process of learning. Both research teachers regard this as a valuable component to be embedded within a pre-service teacher methods unit due to the nature of contemporary teaching and learning contexts.

Academics are being asked to find new ways of teaching to accommodate large classes and incorporate new technologies (Benjamin, 2000; Torrisi-Steele \& Drew, 2013). These changes provide an opportunity to use team teaching as a collaborative tool 'to improve student learning and to develop a scholarly discourse on teaching and student learning' (Benjamin, 2000, p. 192). When team teaching is combined with blended learning, there are further benefits, challenges and complexities that require consideration. Firstly, an outline of the current working model and blended learning and team teaching framework used in this study is necessary to provide further context.

\section{A working model - blended learning and team teaching framework}

There are a number of blended learning models to suit educator, student and institution-based goals and priorities (Clayton Christensen Institute 2015; Gedik et al., 2013; Osguthorpe \& Graham, 2003). However, below are four blended learning models that appear in a number of different education settings, each providing students and educators' flexibility and a diversity of learning environments to consider: 
(1) The rotation model prescribes that students motion through learning activities that cover different modalities, with at least one of these activities being administered online. Due to the diversity of methods, sequence and structure explored within this model, it is classified by an additional four different subsets.

(i) Station rotation: A method offering instructional flexibility. Students rotate through a variety of learning stations/activities, ranging from group discussion to individual online learning and everything in between. The teacher schedules the rotation from one modality to another at their own discretion and as fixed/timed and/or needs-based.

(ii) Lab rotation: A traditional method where students participate in offline learning activities in a brick-and-mortar setting and then change rooms to go and participate in online learning activities in a media or computer lab. The different physical environments set the defined expectations for the online and offline learning.

(iii) The flipped classroom: Students learn face-to-face with an educator in a brick-and-mortar setting. They are then assigned online activities to be completed in a remote setting or out-of-class context, for example, at home, at the library, coffee shop.

(iv) Individual rotation: The individual student motions through a variety of activities and stations defined either at the educator's discretion, via an algorithm-driven learning path or a combination of the two. It's also important to note that the student may not necessarily rotate or switch to each available station or activity, only to those listed in the individual curriculum path.

(2) The flex model: Online learning is the driver and learning occurs in this context while being seated in a brick-and-mortar structure. The educator is available for face-to-face support and structures and facilitates offline activities and group/whole-class discussion on a discretionary or need-be basis. The main premise for this model is to allow the educator more time to work directly with individual students. With less time required for setting up and building basic knowledge as the majority of the learning is done via online instruction resources, there is more time to address the learning needs of individual students.

(3) The a la carte model provides individual students with the choice to take one or more specific online courses with an online educator or facilitator while also taking traditional offline courses. The online courses can be taken at the brick-and-mortar site or a remote site.

(4) The enriched virtual model provides students the chance to split time learning between brick-andmortar courses and online courses. In comparison to the individualised a la carte model, the whole class or entire student cohort completes the exact same course load, schedule and combination of online and offline classes. The enriched virtual model is now being adopted by many educational institutions who began with complete online courses, as it was realised that a traditional offline classroom setting offers the ability to further scaffold learning and develop the critical thinking and collaboration skills often only found in face-to-face settings.

The blended learning approach used in this project is a combination of the station rotation and flipped classroom methods.

There are three basic team teaching styles as described below (Fuller \& Bail, 2011; Letterman \& Dugan, 2004; White, Henley, \& Brabston, 1998):

(1) Participant-observer: Each teacher/lecturer is present for all classes and both teacher/lecturers teaching and instructing. However, they work independently, not together.

(2) Interactive: Each of the teacher/lecturers are present and they work together to teach, instruct and engage with students in discussion.

(3) Rotational: Each teacher/lecturer or faculty teaches different parts of the course, only being present when it is their time to teach. This method requires an excellent level of planning to ensure that there is no overlap or repetition of material, as well as consistency in assessment.

This project uses a combination of elements from all three team teaching styles. It is largely interactive as both lecturers are present for most workshops and plan, teach, instruct and engage with students in a collaborative way. However, there are aspects of independent work (participant-observer) and occasions where expert content and or knowledge is required; therefore; the two lecturers present different aspects of certain topics both in class and online (rotational). 
Figure 1 presents a visual representation of the framework, a working model used when blended learning and team teaching are applied in the context of this project.

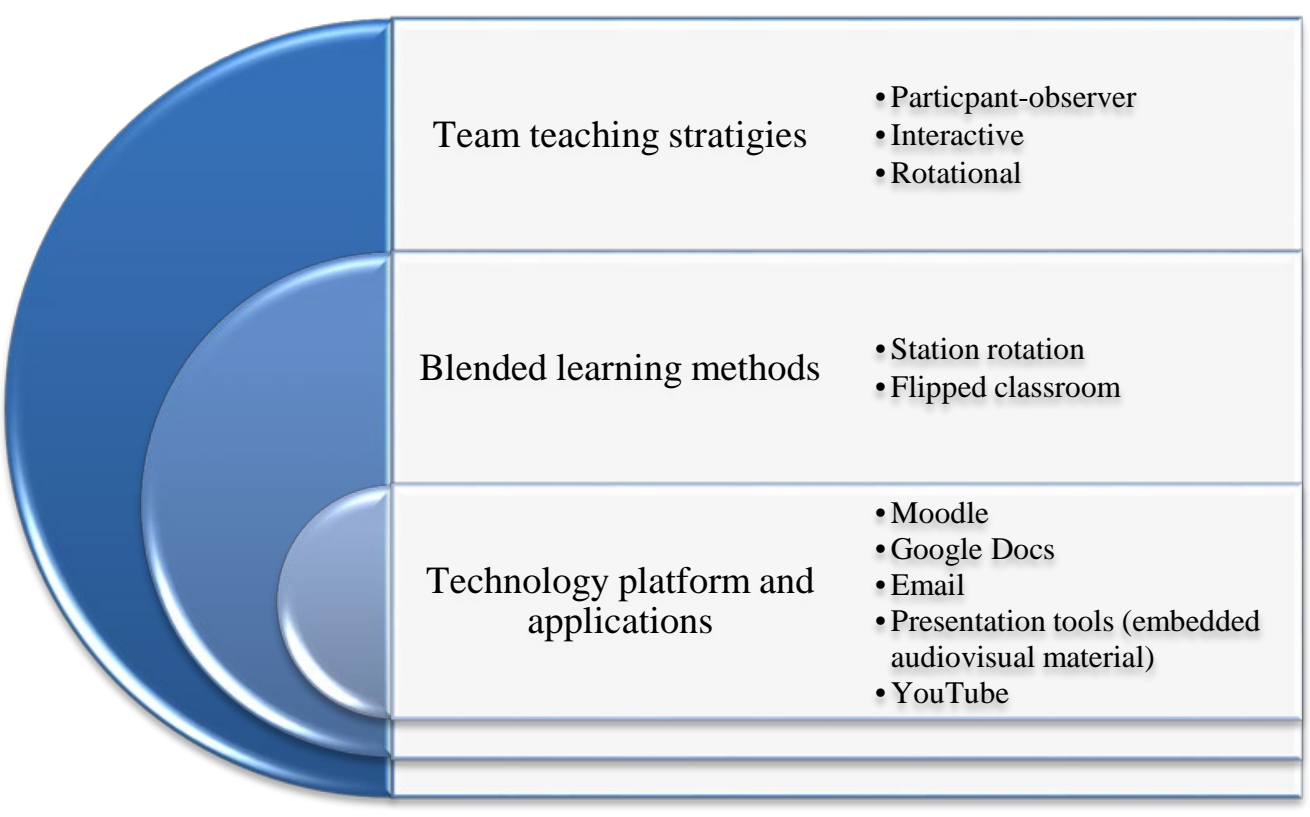

Figure 1. A working model - blended learning and team teaching framework

As indicated by Figure 1, this approach uses technology in a blended learning style that combines the learning management system (LMS) Moodle for delivery and repository of teaching and learning resources and materials, Google Docs, email, presentation tools with embedded audio visual material (e.g., Microsoft PowerPoint), YouTube videos and social networking with traditional face-to-face learning in a workshop space. This section offers a framework as part of a working model, it is expected that this may be refined and adapted as the project progresses.

\section{Methodology}

In order to define and develop an innovative approach to teaching and learning, the following research questions were devised:

- What are pre-service teachers' understandings of blended learning and team teaching?

- How can a combined pedagogical approach using blended learning and team teaching strategies impact the learning of pre-service teachers?

This study uses elements of mixed methodology to investigate these questions, particularly in the various research tools used. Action research is the most appropriate methodological framework, given the nature of the research required and its purpose for this project. This allowed a focus on the issues presented in a localised context with the intention that this could later be applied to a wider context. While action research is not a new approach in educational contexts, it is important to establish the way in which it is used within this study to establish the parameters for validity and credibility. In a symbiotic relationship, action research is essentially taking action based on research and researching the action taken. Pelton (2010) stated that action is what you do as a professional and research includes the methods, habits and attitudes needed to be a reflective practitioner. This is based on the premise that local conditions vary widely and that the solutions to such problems cannot be found in generalised truths that disregard local conditions. While gaining considerable attention in education, action research is also used in a number of other professional settings such as medicine, clinical studies and government units (Noffke \& Somekh, 2009, 2011). The purpose of action research in this study, as in other education research, is to create an inquiry stance where questioning one's own practice becomes part of the work and of the culture. It is a systematic approach that is cyclical in nature, alternating between action and reflection, continuously refining methods and interpretations based on understandings developed in earlier cycles. 
The classroom action research approach described by Hendricks (2009) has been identified as applicable to this research as it concerns teachers in their classroom or tutorial, examining issues and problems to find innovative solutions. The primary purpose of this is to improve classroom or tutorial practice or to improve practices in the school or university and to change theory and practice (Hendricks, 2009). The benefits of using such an action research approach as applied to this study have been defined as:

- developing knowledge directly related to practice and focusing on improving practice

- promoting reflection and use of information for better decision-making

- fostering openness to new ideas and encouraging creativity

- encouraging collaboration and the development of learning communities or partnerships

- encouraging rethinking about how both the educators and students' work is evaluated

- providing rich sources of data that can be used for unit and course development and improvement.

- allowing the articulation of choices made and methods used

- increasing understanding and respect among educators and students

- modelling positive professional practice to pre-service teachers in the course

- modelling various teaching approaches and styles to explore engagement and interest in student learning.

This is by no means an exhaustive list, but it does allow the educators to use research results to improve practice, make informed decisions and model professional practice to pre-service teachers, which align with the objectives of this project.

This research process is recursive, non-linear and essentially cyclical in nature. The literature indicates that it is very systematic, involving specific stages or processes that are strategically repeated in response to research findings (Alber, 2011; Johnson, 2012; Pelton, 2010; Stringer, 2008). While the models of action research may differ, as described in the literature, the cycle and its processes appear to have common elements. It is these common elements that have been used to develop the action research model used in this research project. The following figure is a visual representation of the outline of this the cycle and its individual processes:

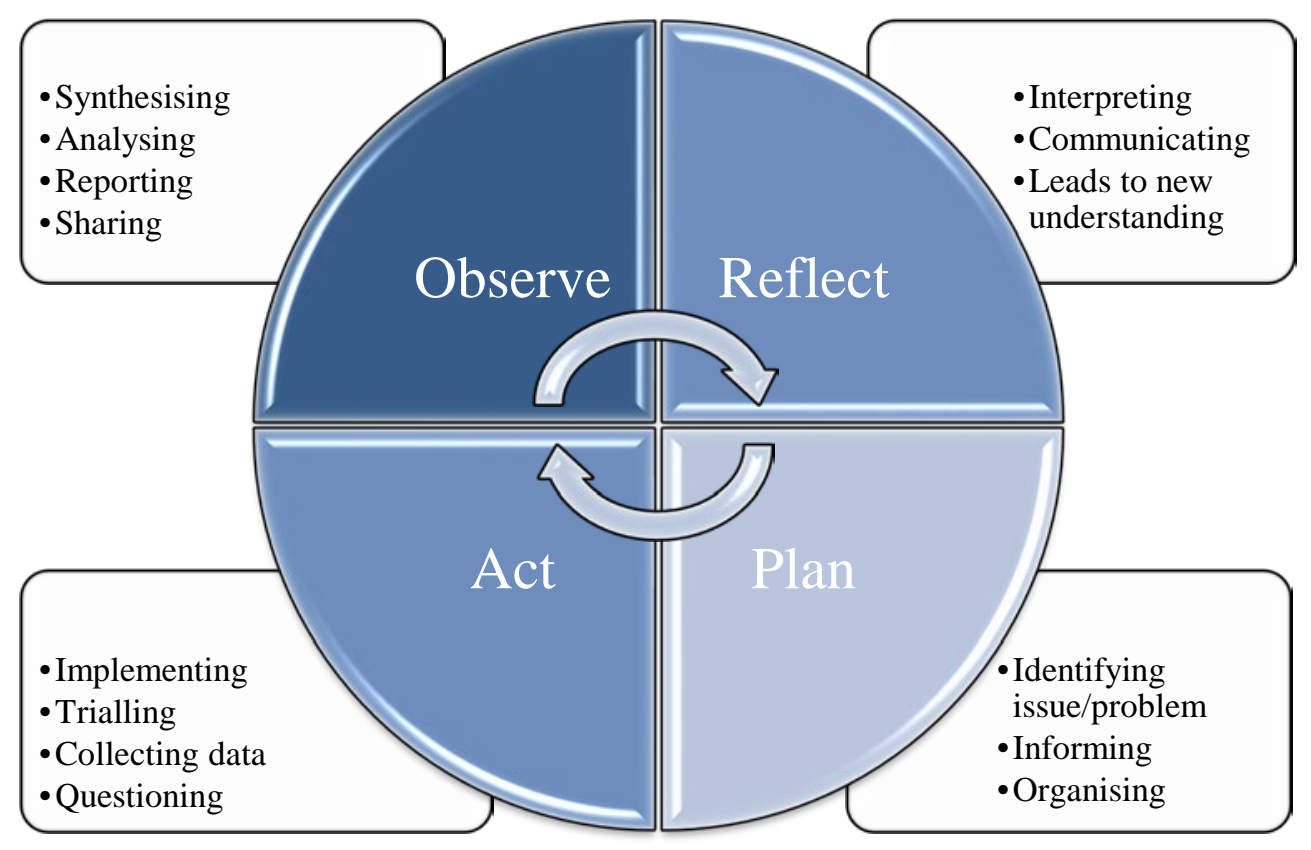

Figure 2. Action research cycle - outline of model applied to this project

The cycle begins from the process of reflection where a problem or issue is identified. A plan is developed and implemented or acted upon, which includes the collection of results. The findings from the results are synthesised and interpreted, which leads to the next cycle, which will be reflective of a new understanding 
of the nature of the problem. Figure 3 represents an extension of this model and an outline of the research design and tools used in this project to date using the model described.

\section{Cycle 1 - Year 1}

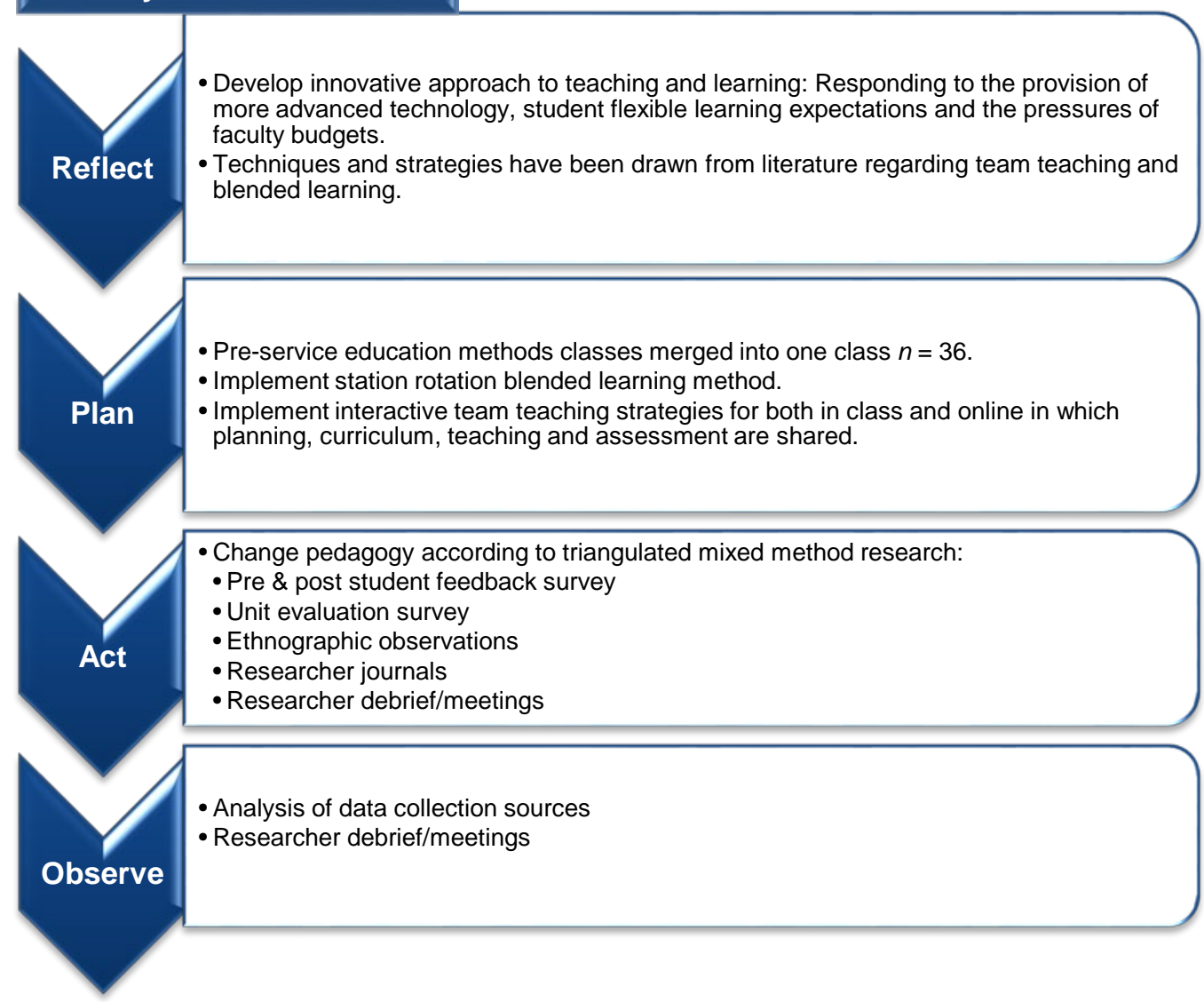

\section{Cycle 2 - Years 2-3}

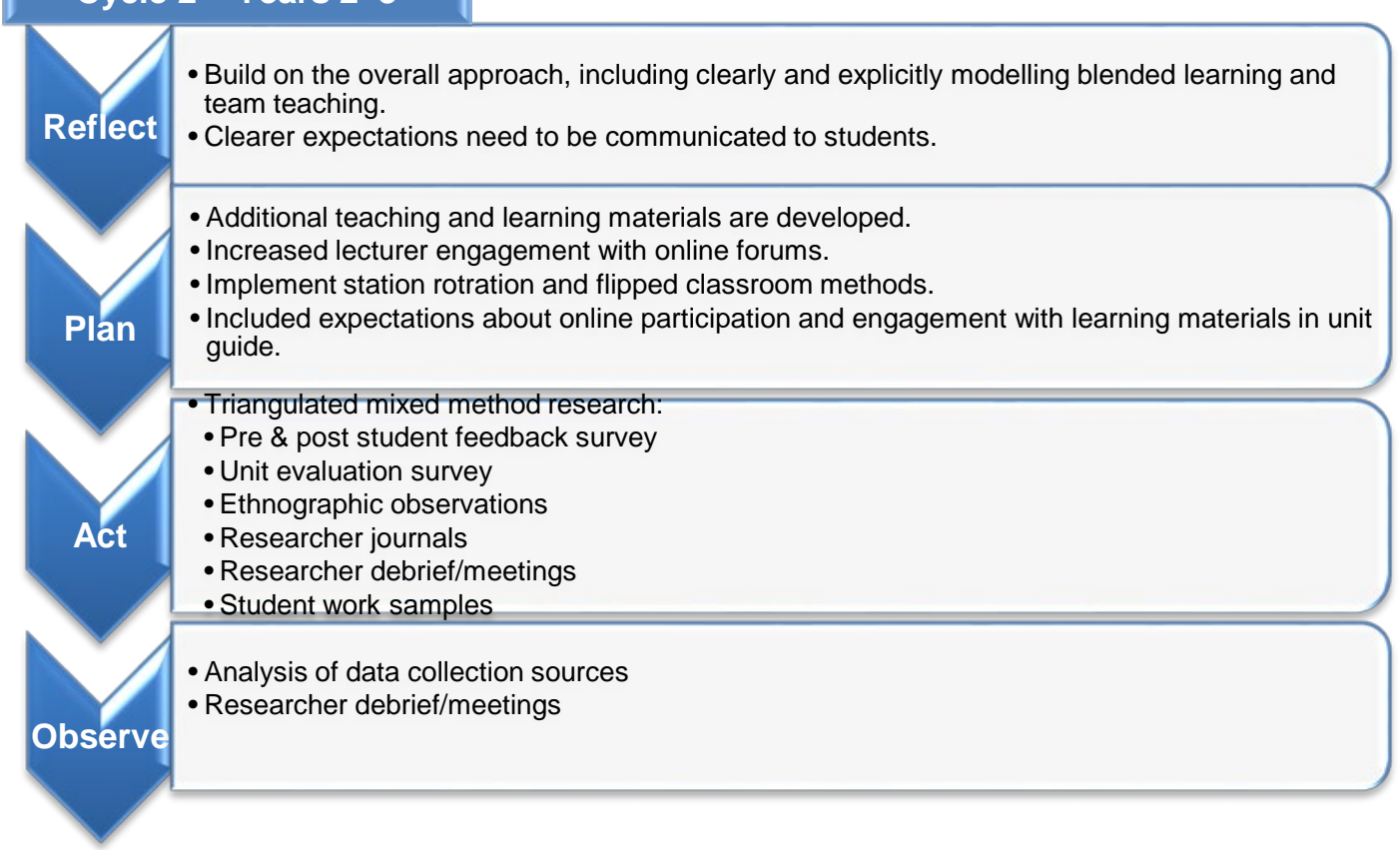

Figure 3. Research design and tools used within an action research model

Cycle 1 represents the first year of the project. Cycle 2 is indicative of the research design used for the two 
subsequent years as a response to the results from cycle 1. Each cycle equates to a semester-long pre-service teacher methods unit in which the study was conducted. The student participants used each year over three years were in their final year completing the initial pre-service secondary teacher course as part of either the postgraduate Diploma of Education, Master of Teaching or undergraduate Bachelor of Education. The number of student participants were as follows: year $1 n=36$; year $2 n=28$; year $3 n=24$; total across $n=$ 88. In order to ascertain pre-service teachers' understandings of blended learning and team teaching and how the combined pedagogical approach impacted their learning, two formal surveys were administered by a third party, pre and post the methods unit. This was done to capture baseline data for each of the three student cohorts in the respective years as well as initial understandings prior to the commencement of the unit. Structured open and closed questions were used allowing for the collection of both qualitative and quantitative data. The pre-unit survey data was then compared to responses at the end of the unit that sought to measure changes in understanding based on the approach employed by the two lectures in the unit.

Action research is sometimes discredited and scrutinised on the premise of lack of rigour or the fact that the researchers are directly involved and therefore certain bias can be perceived (McNiff \& Whitehead, 2000). This misunderstanding and cynicism can be overcome by the production of objective evidence (McNIff \& Whitehead, 2000) through the systematic and rigorous approach applied to methodology as demonstrated in Figure 3. Triangulation of multiple data sources is critical in ensuring rigour of quality, credibility and reliability, which includes the production of objective data. Action research in education often relies on authentic student work and insights, which compared with other forms of primary source materials, can enhance credibility (Sagor, 2000). Credibility is the researcher's ability to take into account the complexities that present themselves in a particular setting and to deal with patterns not easily explained. Mills (2003) asserts if action is to be viewed as credible, the solution to the problem (the planned action) must actually solve the problem. This can also include building on knowledge and understandings towards solving a problem or issue. It is important to acknowledge that generalisability is not the primary goal of action research, rather it is understanding what is happening in a specific context in order to make improvements in that context. Data is not collected simply to validate existing practices. Discrepant data and biases are important to be revealed and understood as they are critical to the process of reflection, a key component of action research which leads to the implementation of changing practice. Although this is an education discipline-based study in a localised context, it is intended that the findings may contribute to the knowledge of developing pedagogy in higher education within other education faculties. The combination of blended learning with team teaching is innovative and is intended to respond to the paucity of research and literature that exists in this field.

Action research can present some unique challenges to overcome with regard to ethical considerations as the nature of the research is more open ended and may change in focus depending on the problem or issue. However, ethical considerations are based on the same principles as ethics in other research involving humans. There is also little distance between the researcher and the subjects; however, it has been established that by following rigorous methodology and having multiple sources of data collection, objective data is still achievable. While the case is made in education that regardless of action research taking place, students are simply and naturally living through the teachers or researchers' instruction (Sagor, 2000), informed consent is applied. Where appropriate, unit evaluations and survey inquiries are anonymous, administered by a person not involved with the unit or class and implied consent is applied in these cases.

Much of what has been written about data analysis in action research mirrors strategies used in qualitative research (Hendricks, 2009; Mills, 2003; Pelton, 2010). This is appropriate given that primarily qualitative methodologies and research tools are used. Data analysis involves reviewing the data while being collected and attempting to synthesise and interpret what is observed. This is termed 'interim analysis' (Pelton, 2010). Analysis can be highly descriptive and involves searching for patterns and trends in the data. Coding data is fundamental to much qualitative research data analyses and is a key analysis strategy relevant to this study. Open coding is used for data reduction and categorisation into manageable segments. Axial coding is used to put the data back together to make connections between and across categories. Selective coding is also used if a category has been identified due to having a prior clear and selective focus; data is reviewed systematically for that specific category. All three types of codes are used in this study for the qualitative data. The small amount of quantitative data generated primarily through survey and unit evaluations are calculated using basic statistics and frequency formulas at this stage. As explained previously, for the 
purpose of exploring the student learning experiences and perceptions about blended learning and team teaching in this study, three years of pre and post student feedback survey data will be presented.

\section{Results from pre-service teacher survey data and discussion}

It was important to discern if students had any preconceived issues or ideas associated with blended learning and team teaching and how this may change through the course of the unit given the approach utilised. The following table displays the frequency of students' responses to this issue pre and post the unit.

Table 1

Percentages of pre and post concerns with blended learning and team teaching

\begin{tabular}{|c|c|c|c|c|c|c|}
\hline \multirow[t]{2}{*}{ 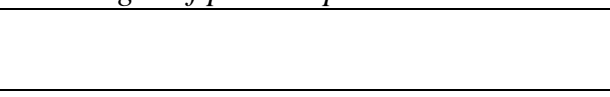 } & \multicolumn{3}{|c|}{ Pre-unit feedback } & \multicolumn{3}{|c|}{ Post-unit feedback } \\
\hline & Yes & No & No answer & Yes & No & No answer \\
\hline \multicolumn{7}{|l|}{ Cycle $1-$ year $1 n=36$} \\
\hline Blended learning concerns & 7 & 57 & 36 & 29 & 57 & 14 \\
\hline Team teaching concerns & 11 & 82 & 7 & 0 & 93 & 7 \\
\hline \multicolumn{7}{|l|}{ Cycle $2-$ year $2 n=28$} \\
\hline Blended learning concerns & 29 & 46 & 25 & 9 & 87 & 4 \\
\hline Team teaching concerns & 18 & 71 & 11 & 0 & 100 & 0 \\
\hline \multicolumn{7}{|l|}{ Cycle 3 - year $3 n=24$} \\
\hline Blended learning concerns & 17 & 46 & 38 & 22 & 65 & 13 \\
\hline Team teaching concerns & 4 & 96 & 0 & 0 & 100 & 0 \\
\hline \multicolumn{7}{|l|}{ Total across 3 years $n=88$} \\
\hline Blended learning concerns & 18 & 50 & 32 & 20 & 69 & 11 \\
\hline Team teaching concerns & 11 & 83 & 6 & 0 & 97 & 3 \\
\hline
\end{tabular}

As a general observation, the 'no answer' column in Table 1 decreased across each cycle from the pre- to post-survey feedback. This may signify an overall change in students' understanding of the modes of learning used and referred to at the conclusion of each cycle. The data related to blended learning will be explored first.

In cycle $1,57 \%$ of students did not have concerns with blended learning pre or post the unit. However, the data showed that not all the students found this mode of learning to be positive. Disappointingly for the researchers, 7\% of students did have concerns about blended learning prior to its implementation, and this increased to $29 \%$ after they had experienced it for a semester. In response to this data the researchers planned a more interactive approach to the blended learning elements used in their pedagogy for cycle 2. This included an increase in an active role-modelling of blended learning and more focused discussion about the purpose of implementing particular activities and processes. It is also important to note that students involved in cycle 1 were in transition from the LMS Blackboard to Moodle. Learning to navigate through the new LMS may have been an influencing factor on the results, as in many ways this data did not reflect the current preponderance of technology in society. Cycle 2 showed more positive results with the percentage of students who had concerns about blended learning falling from $29 \%$ in the pre survey to $9 \%$ in the post survey. In cycle 3 although the percentage of student with concerns slightly increased in the post survey from $17 \%$ to $22 \%$, students who did not have concerns increased from $46 \%$ to $65 \%$. This suggested the researchers' efforts impacted positively in cycles 2 and 3. The following table demonstrates qualitative examples of student feedback across the three years providing further insight into students' understanding of blended learning and why they believe it was being implemented. 
Table 2

Qualitative data: Understanding of blended learning

\begin{tabular}{|c|c|c|c|c|}
\hline & $\begin{array}{l}\text { Pre-unit response } \\
\text { Understanding of } \\
\text { the term 'blended } \\
\text { learning'? }\end{array}$ & $\begin{array}{l}\text { Why implement } \\
\text { blended } \\
\text { learning? }\end{array}$ & $\begin{array}{l}\text { Post-unit response } \\
\text { Understanding of the } \\
\text { term 'blended learning'? }\end{array}$ & $\begin{array}{l}\text { Why implement } \\
\text { blended } \\
\text { learning? }\end{array}$ \\
\hline \multicolumn{5}{|c|}{ Cycle 1 - year 1} \\
\hline $\begin{array}{l}\text { Student no. } \\
1\end{array}$ & $\begin{array}{l}\text { Integrating } \\
\text { different areas of } \\
\text { learning, as well } \\
\text { as different modes } \\
\text { of delivery and } \\
\text { technologies. }\end{array}$ & $\begin{array}{l}\text { In order to give } \\
\text { us the opportunity } \\
\text { to learn from this } \\
\text { strategy and then } \\
\text { implement it in } \\
\text { our own teaching. }\end{array}$ & $\begin{array}{l}\text { Integrating different subject } \\
\text { areas, different resources } \\
\text { and media to offer a } \\
\text { program that is relevant to } \\
\text { all areas of our teaching. }\end{array}$ & $\begin{array}{l}\text { To help us to help } \\
\text { ourselves, to offer } \\
\text { different sources } \\
\text { for learning. } \\
\text { Sometimes } \\
\text { Moodle can be a } \\
\text { little } \\
\text { overwhelming } \\
\text { with all of the } \\
\text { forums. It can be } \\
\text { difficult at times } \\
\text { to source the right } \\
\text { information. }\end{array}$ \\
\hline $\begin{array}{l}\text { Student no. } \\
4\end{array}$ & $\begin{array}{l}\text { Learning through } \\
\text { more than one } \\
\text { teaching style? } \\
\text { Unsure... }\end{array}$ & $\begin{array}{l}\text { So the students } \\
\text { have access to as } \\
\text { much information } \\
\text { as possible. }\end{array}$ & $\begin{array}{l}\text { The use of online learning } \\
\text { and learning in person. }\end{array}$ & $\begin{array}{l}\text { To take advantage } \\
\text { of our ICT skills } \\
\text { and the fact that } \\
\text { we're online often. }\end{array}$ \\
\hline $\begin{array}{l}\text { Student no. } \\
11\end{array}$ & $\begin{array}{l}\text { Using a variety of } \\
\text { ways to teach and } \\
\text { learn (through } \\
\text { materials such as } \\
\text { computers). }\end{array}$ & $\begin{array}{l}\text { Build familiarity } \\
\text { with technology } \\
\text { and how to } \\
\text { incorporate it } \\
\text { usefully and } \\
\text { successfully in } \\
\text { classes. }\end{array}$ & $\begin{array}{l}\text { Computerised resources } \\
\text { plus face-to-face classes. }\end{array}$ & $\begin{array}{l}\text { University policy! } \\
\text { Plus developing } \\
\text { their own skills at } \\
\text { using } \\
\text { Moodle... and } \\
\text { encouraging us to } \\
\text { use/accept } \\
\text { technology for } \\
\text { learning not } \\
\text { socialising etc. }\end{array}$ \\
\hline \multicolumn{5}{|c|}{ Cycle 2 - year 2} \\
\hline $\begin{array}{l}\text { Student no. } \\
6\end{array}$ & $\begin{array}{l}\text { Everyone works as } \\
\text { a group to learn. } \\
\text { People sharing } \\
\text { their views and } \\
\text { opinions. }\end{array}$ & $\begin{array}{l}\text { More interactive } \\
\text { approach to } \\
\text { teaching, students } \\
\text { can learn off each } \\
\text { other. }\end{array}$ & $\begin{array}{l}\text { Integration of ICT in both } \\
\text { in class and out of class } \\
\text { activities/tasks/assessments. }\end{array}$ & $\begin{array}{l}\text { Encourages } \\
\text { collaboration. } \\
\text { Better and } \\
\text { increased access to } \\
\text { resources, ideas } \\
\text { and discussions. } \\
\text { Access to } \\
\text { lecturers. }\end{array}$ \\
\hline $\begin{array}{l}\text { Student no. } \\
15\end{array}$ & $\begin{array}{l}\text { Education that } \\
\text { combines face-to- } \\
\text { face classroom } \\
\text { methods with } \\
\text { computer- } \\
\text { mediated } \\
\text { activities. }\end{array}$ & $\begin{array}{l}\text { Because we can } \\
\text { compile all the } \\
\text { discussions we } \\
\text { had in class and } \\
\text { share the } \\
\text { resources online. }\end{array}$ & $\begin{array}{l}\text { ICT incorporation and } \\
\text { online shared resources. }\end{array}$ & $\begin{array}{l}\text { To encourage } \\
\text { personal reflection } \\
\text { and peer } \\
\text { collaboration. }\end{array}$ \\
\hline $\begin{array}{l}\text { Student no. } \\
25\end{array}$ & $\begin{array}{l}\text { Theory and } \\
\text { practice blurred. }\end{array}$ & $\begin{array}{l}\text { Relevant to our } \\
\text { future teaching. }\end{array}$ & $\begin{array}{l}\text { Classroom and online } \\
\text { delivery/assessment. }\end{array}$ & $\begin{array}{l}\text { Increased } \\
\text { resources and } \\
\text { feedback. }\end{array}$ \\
\hline \multicolumn{5}{|c|}{ Cycle 3 - year 3} \\
\hline $\begin{array}{l}\text { Student no. } \\
9\end{array}$ & $\begin{array}{l}\text { I'm not sure, but is } \\
\text { it integrating } \\
\text { classroom learning }\end{array}$ & $\begin{array}{l}\text { So that we can } \\
\text { cover a broader } \\
\text { range of topics - } \\
\text { also because it's }\end{array}$ & $\begin{array}{l}\text { Online/Moodle activities } \\
\text { with workshops. }\end{array}$ & $\begin{array}{l}\text { Because it requires } \\
\text { us to continue } \\
\text { engaging in the } \\
\text { learning material }\end{array}$ \\
\hline
\end{tabular}




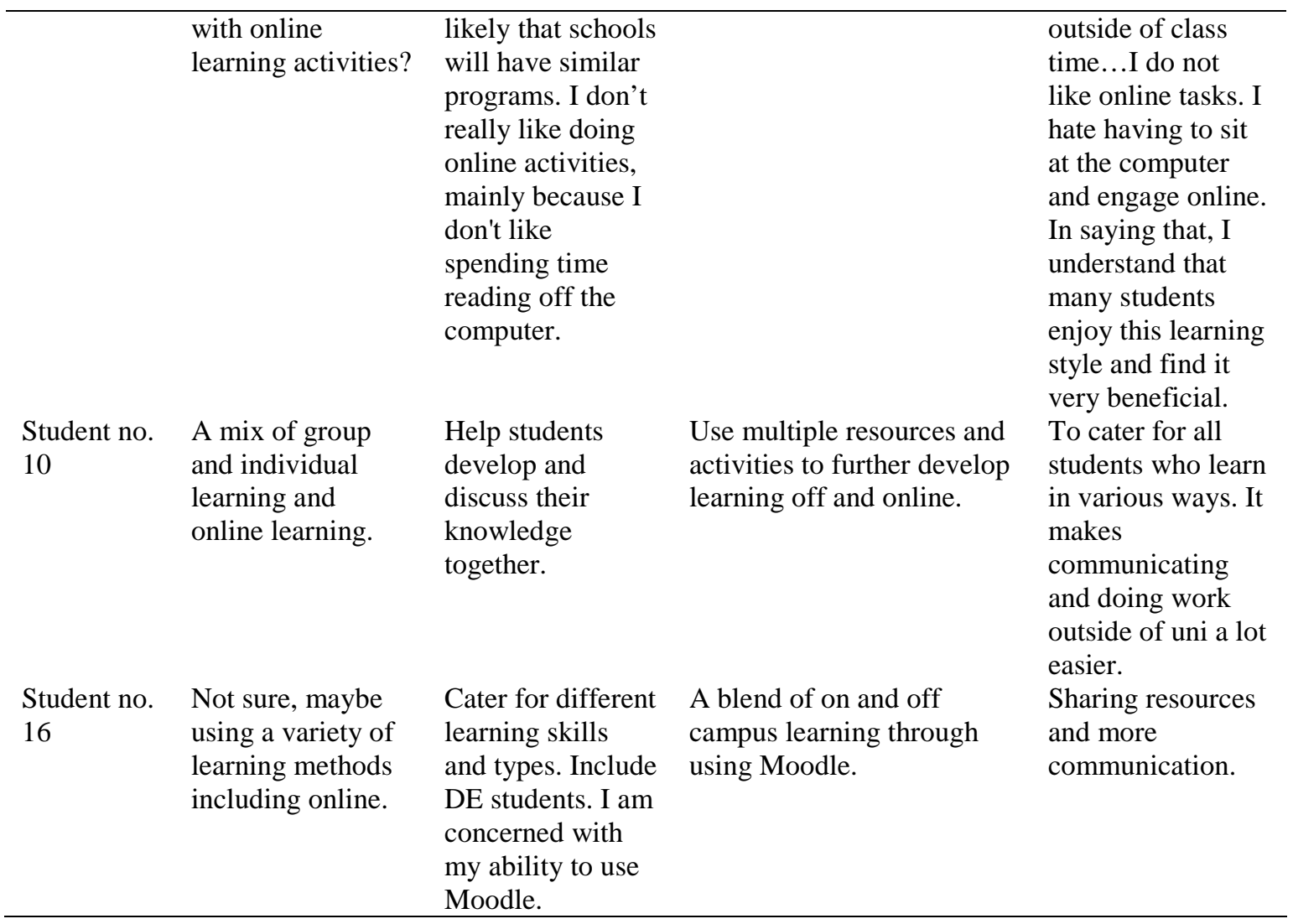

The qualitative comments generated data that highlighted students' level of understanding and misunderstanding about blended learning. In many cases students were able to articulate a definition that resonated contemporary thinking (Garrison \& Kanuka, 2004; Gedik et al., 2013; Lim \& Yoon, 2008; Osguthorpe \& Graham, 2003) at the conclusion of the unit. Questions were provided to stimulate thinking about why their two lecturers used blended learning and how this could impact their learning. Figure 4 is representative of the primary themes that came out of some of the qualitative data across the three years. 


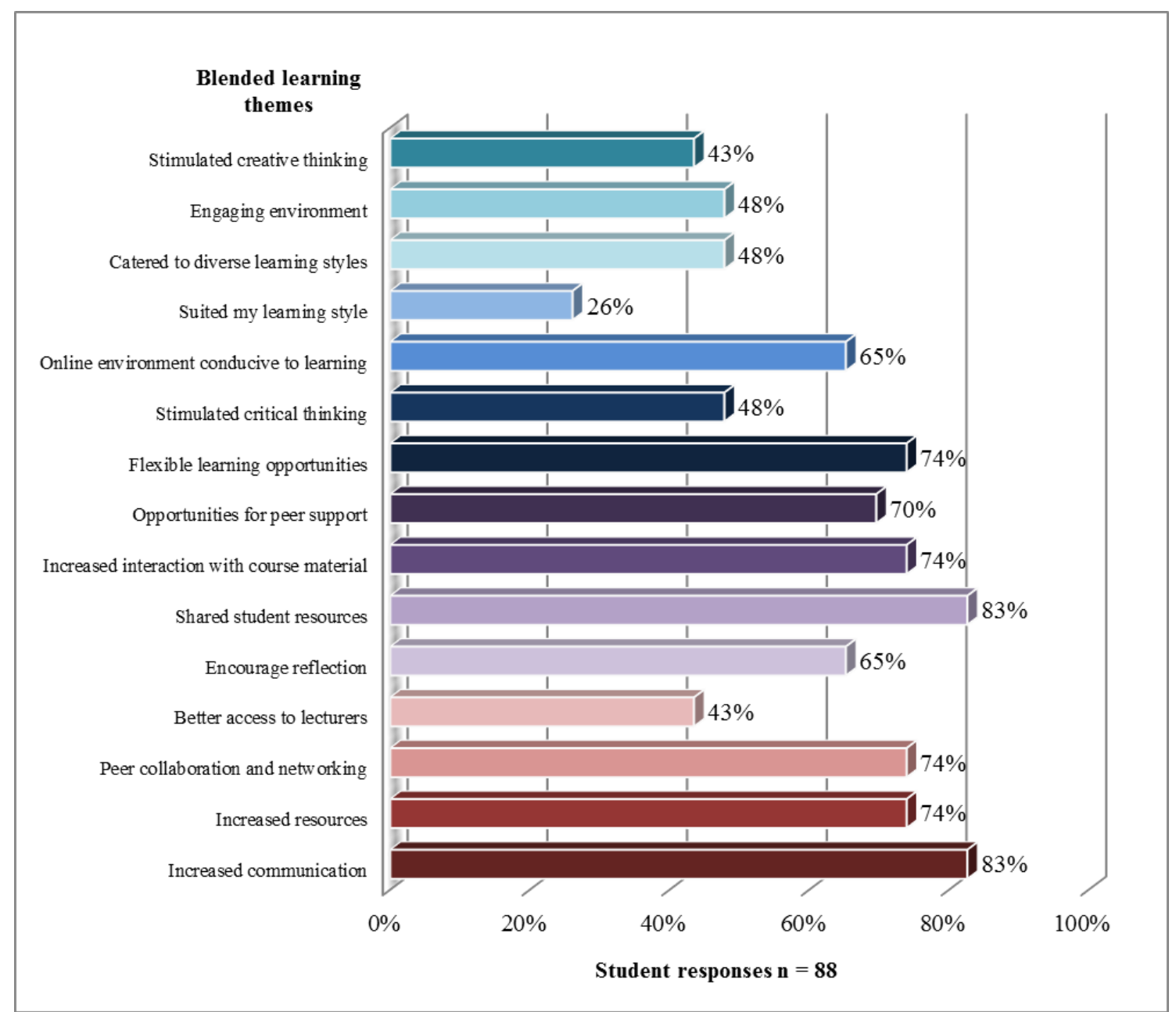

Figure 4. Blended learning themes

As indicated in Figure 4, opportunities for increased communication and resources, peer collaboration and networking and flexible learning were aspects of blended learning that appeared to be valued by the students involved in the study. Technology as a skill to be developed, modelling the use of technology in the classroom from a pre-service teacher perspective and changing university models and policy were understandings encompassed within these themes that emerged from the qualitative data. Many students made the connection with increased use of online activity, supporting Rosenburg's (2006) assertion that the leveraging of technology and social networking supports this particular teaching approach. Regardless of whether these pre-service teachers felt that blended learning was conducive to their learning style, many demonstrated that they understood the potential value, particularly given that blended learning has been described as 'the future' of learning (American University of Beirut, 2010). The data also indicated that students valued the face-to-face component, which was evident from the feedback about team teaching, which will now be considered.

Table 1 shows that the number of students who expressed concern before the commencement of the unit is considerably less and in fact decreases each year of the project, suggesting that students are generally more familiar with the term team teaching than blended learning. Cycle 1 data indicates that the team teaching strategies used had a positive impact; the $11 \%$ of students who were initially concerned with team teaching were no longer concerned by the end of the unit and consequently the percentage who were not concerned increased from $82 \%$ to $93 \%$. In cycles 2 and $3100 \%$ of students involved indicated that their concerns had been alleviated at the conclusion of the unit. The following qualitative comments provide some insight into this numerical data regarding the team teaching element of this pedagogical approach. 
Table 3.

Qualitative data: Understanding of team teaching

\begin{tabular}{|c|c|c|c|c|}
\hline & \multicolumn{2}{|c|}{ Pre-unit response } & \multicolumn{2}{|c|}{ Post-unit response } \\
\hline & $\begin{array}{l}\text { Understanding } \\
\text { of the term } \\
\text { 'team teaching'? }\end{array}$ & $\begin{array}{l}\text { Why implement team } \\
\text { teaching? }\end{array}$ & $\begin{array}{l}\text { Understanding of } \\
\text { the term 'team } \\
\text { teaching'? }\end{array}$ & $\begin{array}{l}\text { Why implement } \\
\text { team teaching? }\end{array}$ \\
\hline \multicolumn{5}{|c|}{ Cycle 1 - year 1} \\
\hline Student no. 7 & $\begin{array}{l}\text { More than one } \\
\text { teacher sharing } \\
\text { the teaching of a } \\
\text { subject. }\end{array}$ & $\begin{array}{l}\text { To give us two } \\
\text { perspectives/views on } \\
\text { the topics. It allows for } \\
\text { individual questioning } \\
\text { without disrupting the } \\
\text { whole class. }\end{array}$ & $\begin{array}{l}2 \text { teachers or more } \\
\text { sharing the load of } \\
\text { preparation and } \\
\text { presenting material. }\end{array}$ & $\begin{array}{l}\text { Share and combine } \\
\text { your ideas to give } \\
\text { us the best } \\
\text { preparation } \\
\text { possible for our } \\
\text { teaching lives. }\end{array}$ \\
\hline Student no. 17 & $\begin{array}{l}\text { 7Multiple teachers } \\
\text { teaching the same } \\
\text { content. }\end{array}$ & $\begin{array}{l}\text { To allow more content } \\
\text { \& perspectives to be } \\
\text { covered and to provide } \\
\text { more experiences and } \\
\text { ideas. Not concerned in } \\
\text { regards to learning, but } \\
\text { in how to team teach } \\
\text { effectively. }\end{array}$ & $\begin{array}{l}\text { Having } 2+\text { teachers } \\
\text { present at a time, } \\
\text { actively planning, } \\
\text { teaching, } \\
\text { participating in } \\
\text { classes. }\end{array}$ & $\begin{array}{l}\text { It broadens the } \\
\text { knowledge in the } \\
\text { class and provides } \\
\text { more ideas and } \\
\text { experiences...It } \\
\text { was good having } \\
\text { two opinions. I } \\
\text { would have liked if } \\
\text { there was more of } \\
\text { an opportunity to } \\
\text { have both teachers } \\
\text { "active" at the } \\
\text { same time. }\end{array}$ \\
\hline Student no. 24 & $\begin{array}{l}\text { 4Two or more } \\
\text { teachers } \\
\text { delivering a } \\
\text { curriculum, } \\
\text { allowing for more } \\
\text { teacher discourse } \\
\text { and if the two } \\
\text { teachers have a } \\
\text { good rapport, the } \\
\text { experience can be } \\
\text { more engaging. } \\
\end{array}$ & $\begin{array}{l}\text { Allows for more } \\
\text { discussion between a } \\
\text { larger cohort and } \\
\text { prompting from two } \\
\text { teachers. It helps the } \\
\text { classroom dynamic and } \\
\text { engagement. It is easier } \\
\text { for quieter students to } \\
\text { blend into the } \\
\text { background in a larger } \\
\text { cohort. }\end{array}$ & $\begin{array}{l}\text { The role of two } \\
\text { teachers leading or } \\
\text { guiding a class. }\end{array}$ & $\begin{array}{l}\text { Because of the } \\
\text { positive impact that } \\
\text { their mutual } \\
\text { rapport for each } \\
\text { other has had on } \\
\text { their classroom } \\
\text { management. }\end{array}$ \\
\hline \multicolumn{5}{|c|}{ Cycle 2 - year 2} \\
\hline Student no. 1 & $\begin{array}{l}\text { Using more than } \\
\text { one teacher to } \\
\text { take a class. }\end{array}$ & $\begin{array}{l}\text { To prepare us for a real } \\
\text { school setting. }\end{array}$ & $\begin{array}{l}\text { Two teachers } \\
\text { planning and } \\
\text { delivering content for } \\
\text { a class. }\end{array}$ & $\begin{array}{l}\text { It is a good e.g. of } \\
\text { collaboration, } \\
\text { increases } \\
\text { knowledge, } \\
\text { provides clear } \\
\text { advice, draws on } \\
\text { different } \\
\text { experiences and } \\
\text { models this } \\
\text { practice for our } \\
\text { own teaching. }\end{array}$ \\
\hline Student no. 9 & $\begin{array}{l}\text { Working in a } \\
\text { group and sharing } \\
\text { the responsibility. }\end{array}$ & $\begin{array}{l}\text { Able to bring a wider } \\
\text { range of knowledge } \\
\text { and personal } \\
\text { experiences. }\end{array}$ & $\begin{array}{l}\text { Two teachers } \\
\text { working together to } \\
\text { deliver a class at a } \\
\text { high standard using } \\
\text { both of the teachers' } \\
\text { knowledge on the } \\
\text { subject. }\end{array}$ & $\begin{array}{l}\text { Double the } \\
\text { experience. None } \\
\text { of my other } \\
\text { subjects use team } \\
\text { teaching, but I } \\
\text { thoroughly enjoy it } \\
\text { and think it's very } \\
\text { useful. }\end{array}$ \\
\hline
\end{tabular}




$\begin{array}{cl}\text { Student no. 25Teachers } & \text { Gives us a chance to } \\ \text { collaborating } & \text { view different teaching } \\ \text { together to teach } & \text { being modelled, } \\ \text { a group. } & \begin{array}{l}\text { provides increased } \\ \text { stimulation. }\end{array}\end{array}$

Shared content Different subject delivery to maximise knowledge and engagement and interests allowed increase expert for a unique perspective. approach. Another level of 'care'. More support and encouragement.

\begin{tabular}{|c|c|c|c|c|}
\hline \multicolumn{5}{|c|}{ Cycle 3 - year 3} \\
\hline Student no. 9 & $\begin{array}{l}\text { Two or more } \\
\text { teachers working } \\
\text { and teaching } \\
\text { together, sharing } \\
\text { knowledge and } \\
\text { expertise. One } \\
\text { teacher will } \\
\text { probably lead the } \\
\text { activity, while the } \\
\text { other provides } \\
\text { support for } \\
\text { students. }\end{array}$ & $\begin{array}{l}\text { It provides the students } \\
\text { with greater access to } \\
\text { learning tools and } \\
\text { experiences. It's very } \\
\text { effective as long as the } \\
\text { teachers are on the } \\
\text { same page and support } \\
\text { each other. }\end{array}$ & $\begin{array}{l}\text { Where teachers work } \\
\text { together in teaching a } \\
\text { class. One teacher } \\
\text { might run one section } \\
\text { of the lesson while } \\
\text { the other teacher } \\
\text { observes and helps } \\
\text { out. }\end{array}$ & $\begin{array}{l}\text { Accessibility and to } \\
\text { give us as much } \\
\text { knowledge and } \\
\text { different } \\
\text { experiences/skills/ } \\
\text { perspectives as } \\
\text { possible. }\end{array}$ \\
\hline Student no. 2 & $\begin{array}{l}\text { Bouncing ideas } \\
\text { off each other, } \\
\text { but working } \\
\text { together to teach } \\
\text { and convey ideas, } \\
\text { instructions. }\end{array}$ & $\begin{array}{l}\text { Provide greater } \\
\text { learning opportunities } \\
\text { so we can draw from a } \\
\text { wide range of skills } \\
\text { and experience. }\end{array}$ & $\begin{array}{l}\text { When two lecturers } \\
\text { share the } \\
\text { management and } \\
\text { content of one class. } \\
\text { I think when two } \\
\text { teachers have a good } \\
\text { rapport with each } \\
\text { other and the class, it } \\
\text { can work really well. }\end{array}$ & $\begin{array}{l}\text { This has been } \\
\text { fantastic - } \\
\text { especially two such } \\
\text { talented and } \\
\text { helping teachers! } \\
\text { It's been great } \\
\text { hearing a range of } \\
\text { stories and } \\
\text { experiences from } \\
\text { both lecturers. } \\
\text { So that we can } \\
\text { have access to a } \\
\text { wider range of } \\
\text { experiences and } \\
\text { ideas and one on } \\
\text { one (small group) } \\
\text { teaching. }\end{array}$ \\
\hline Student no. 2 & $\begin{array}{l}2 \text { More than one } \\
\text { teacher working } \\
\text { with a class, both } \\
\text { individually and } \\
\text { together - using } \\
\text { each other's } \\
\text { strengths. }\end{array}$ & $\begin{array}{l}\text { Covers more } \\
\text { knowledge and more } \\
\text { opinions. }\end{array}$ & $\begin{array}{l}\text { Two teachers } \\
\text { working with a class } \\
\text { as part of a team. }\end{array}$ & $\begin{array}{l}\text { Demonstrates } \\
\text { collaboration a } \\
\text { partnership, } \\
\text { different } \\
\text { experiences and } \\
\text { how to respect } \\
\text { values and } \\
\text { opinions. To } \\
\text { expose us to more } \\
\text { knowledge and } \\
\text { ways of thinking. }\end{array}$ \\
\hline
\end{tabular}

Exploring students' understanding of what team teaching is, initiating thinking about why their lecturers implemented this approach and how it will impact their learning is critical in the development of this innovative teaching approach and fulfilling the study objectives. Table 3 presents examples chosen to demonstrate the majority of student responses. There appeared to be a consistent understanding among the students of some of the elements that team teaching entails. This is further highlighted in Figure 5, which is representative of the primary themes that came out of some of the qualitative data across the three years regarding team teaching. 


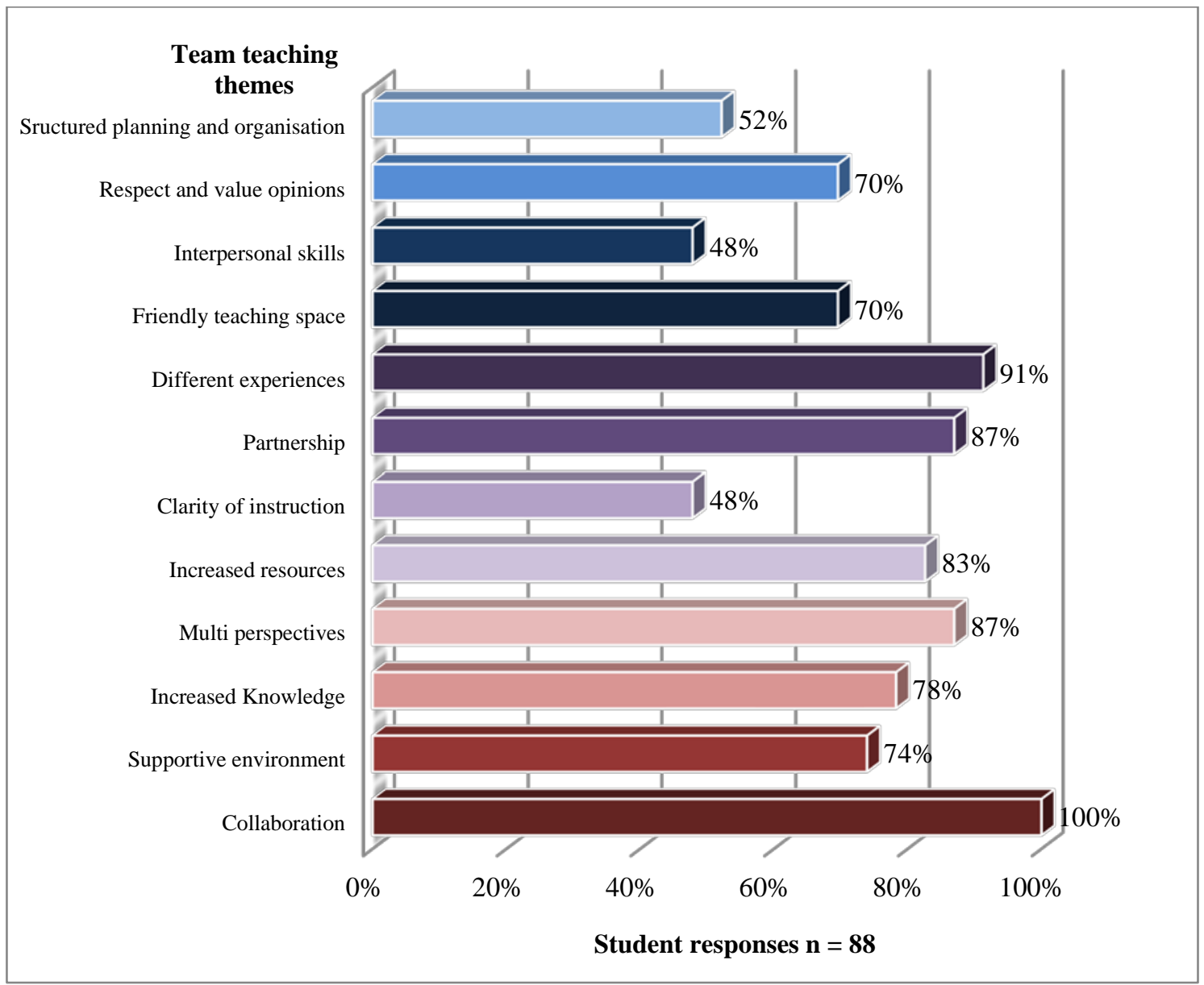

Figure 5. Team teaching themes

Results indicate that collaboration, different experiences and multi-perspectives were the three most significant aspects students identified in team teaching. The theme of collaboration is recognised by the students in this sense to mean teacher collaboration as opposed to when identified as beneficial to blended learning in regards to increasing student peer collaboration and networking. These results were encouraging as the researchers had particularly focused on creating a supportive learning environment through collaborative opportunities, the sharing of resources and the provision of two lecturers with quite different life and work experiences. From both a teacher and student lens, peer-to-peer partnerships and support were also encouraged throughout the semester. The recurring themes presented in Figure 5 suggest that team teaching allowed for an overall positive student learning experience. Clarity of instruction and the importance of interpersonal skills were only identified by $48 \%$ of the total cohort. While this may indicate that these aspects of team teaching are not valued as highly as some others, they are still identified as contributing to team teaching.

Overall, there was a fairly consistent understanding among the students of some of the elements of the approach developed by the lecturers. This highlighted that intentions and strategies adopted in this pedagogy were mostly understood by students (Benjamin, 2000). Specific themes such as collaboration, shared knowledge, the value of diverse experiences, perspectives or opinions, the importance of rapport between the educators and increased assistance and modelling team teaching align with the benefits of this approach identified in the literature (Boulay, 2005; Donnison et al., 2009; Farey, 1974; Fuller \& Bail, 2011; Haddon, 2011; Mansell, 2006; Shibley, 2006). This exemplifies the impact that team teaching can have on the modelling of education practice and the future work of pre-service teachers, 'During my placement I was able to team teach with my mentor. Having that initial example from Teacher 1-Teacher 2 and Teacher 2-Teacher 1 really helped' (cycle 1 - student no. 18). Exploring alternative structures, strategies and approaches to teaching is critical in contemporary education to ensure that pre-service teachers are ready for the requirements of a flexible and rapidly changing teaching and learning environment. 
The data represented in Figure 6 is indicative of whether students valued the blended learning and team teaching approach and whether they would feel comfortable implementing this in their own classroom.

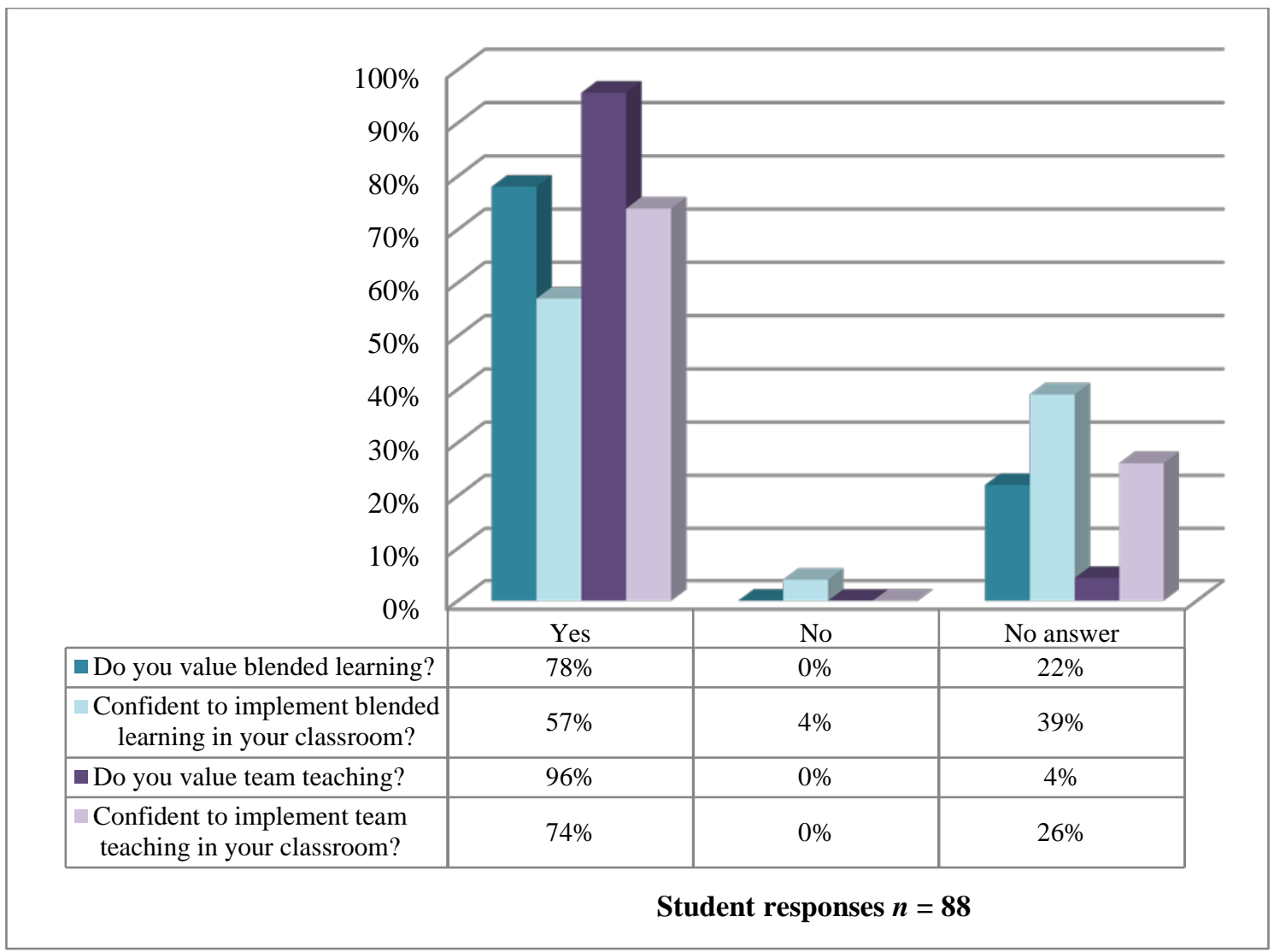

Figure 6. Value and confidence to implement blended learning and team teaching in the classroom

After their learning experience, 78\% of pre-service teachers valued the blended learning elements of the approach used. However, only 57\% indicated that they were confident in implementing it themselves. This was less than the $74 \%$ of pre-service teachers who clearly were more confident about using team teaching in their classroom. Students who did not provide an answer expressed in the qualitative data that they were mostly unsure how to respond. This is valuable data in thinking about the pedagogical approach overall and in particular how to address this issue of pre-service teacher confidence in practising blended learning. While the research teachers will revise their pedagogical approach in response, including more in-class micro-teaching opportunities to practise and discuss blended learning, it is acknowledged that each student cohort will differ in skills and knowledge. Data from Table 2 and Figure 4 suggests that pre-service teachers recognise the value of blended learning and that students' understanding of the approach itself has increased with each progressive year. The data elucidated a key element in the pedagogical approach that combines blended learning and team teaching-regardless of the medium, teacher quality is central to accompanying effective and meaningful learning activities and resources in both in class and online environments (Lim \& Yoon, 2008).

\section{Conclusion}

This study reported on three sequential years of findings, which explored student understandings of blended learning and team teaching and the overall impact they had on their learning. This was a teacher-led research project devised to navigate through some of the complexities and implications associated with necessary pedagogical change in response to the transitioning digital tertiary environment. The development and implementation of blended learning and team teaching strategies were introduced into the pedagogy of a tertiary pre-service teacher education methods class. This paper has reported on findings from the student perspective across a 3-year period that represents three cycles of student survey data. The authors concluded 
from this data that team teaching had a positive impact overall, while blended learning had a gradual and more conservative influence on the student cohort.

The data indicates that the meaning and understanding of blended learning and team teaching improved progressively across the three years with each respective student cohort. In general, the term and elements of team teaching were better understood than blended learning. It is reasonable to suggest that this may be a result of the more recent introduction of the approach in educational spheres and slower adoption in tertiary contexts. However, with the leveraging of social networking (Rosenburg, 2006) and increase in the use of innovative learning technologies (Thorne, 2003), this approach will likely become an embedded part of the tertiary learning process Gedik et al., 2013; Montgomery et al., 2015), leading to a more sophisticated understanding. It still remains that a definition and frame of reference from the combined approach of blended learning and team teaching is required.

Research in blended learning and results from this study suggest that both the face-to-face and online components need to be complementary and interdependent to be successful (Francis \& Shannon, 2013; Montgomery et al., 2015). In such a context technology should be seamlessly integrated into the instructional design and teaching process (Torrisi-Steele \& Drew, 2013; Turney, Robinson, Lee, \& Soutar, 2009). Thoughtful pedagogical planning by a discipline expert is required in order to ensure learning activities are relevant and meaningful (So \& Brush, 2008). A layer of complexity is added when collaborating in a team teaching capacity as flexibility is required to accommodate different opinions and negotiation of curriculum content, engagement and delivery. While it is recognised that blended learning is a preferred flexible learning option for many students and to an extent thought to relieve budgetary pressure, there is increased time and work load to the academics on the teaching team (Mansell, 2006).

The findings from the student survey data substantiated that there are benefits from combining the blended learning and team teaching approach. Qualitative data were provided as examples representative of the overall student cohort and used to further illustrate the context of the quantitative data. There is an overlap of some key themes and ideas identified by students in both blended learning and team teaching contexts, which include collaboration, sharing resources and knowledge and modelling the use of technology and team teaching as a basis for their own teaching practice. It was indicated that experiences with blended learning and team teaching increase the overall focus on learning and improved students' engagement (Donnison et al., 2009; Fuller \& Bail, 2011; Haddon, 2011; Lim \& Yoon, 2008; Shibley, 2006). The overall positive outcomes demonstrated can be further illuminated by identifying areas of consistency and contrast in the student experience from year to year. Literature further supports the notion that blended learning and team teaching may result in many benefits for students and educators (American University of Beirut, 2010; Benjamin, 2000; Donnison et al., 2009; Haddon, 2011; Lim \& Yoon, 2008; Rosenburg, 2006; Shibley, 2006). However, research has not yet provided extensive insight into the impact of the combination of the two approaches; a research gap being addressed by this project.

Overall, the data does inform the ongoing development of the unit teaching materials and pedagogical approach. It is intended that these preliminary findings and such an approach may be considered by education faculties in other institutions. As the project continues to evolve, a more refined pedagogical model that clearly articulates the combined blended learning and team teaching approach will be developed. Increased accessibility of advanced technology, the targeted use of online learning platforms, student flexible learning expectations and the pressures of faculty budget constraints and priorities have called into question the effectiveness of traditional tertiary teaching and learning models. The tertiary education context must evolve at a pace consistent with the growing expectations and requirements of an innovative society. This project directly responds to necessary pedagogical reform in an expeditiously changing digital tertiary environment.

The development and implementation of blended learning and team teaching strategies had positive outcomes on both the learning and teaching in this pre-service methods unit. Students were also able to draw links between the pedagogical approach taken in the unit to their own developing teacher practice. While this was a learning intention, the connections the pre-service teachers made developed quite organically as a result of the combined methods used by the research teachers. Exploring alternative structures, strategies and approaches to teaching is critical in modelling good practice, which is particularly pertinent in the context of pre-service teacher education. This is also important in contemporary education more generally, to ensure that the new generation of teachers are ready for the requirements of a flexible 
and rapidly changing teaching and learning environment. While students indicated that they were more confident in utilising team teaching strategies, rather than blended learning in the classroom, there is a clear indication of the valued potential and the willingness to develop these innovative skills and approaches.

This project will continue to use an action-based research style to refine and develop the pedagogy discussed in this paper. As an extension to this study, it will be valuable to consider how this blended learning and team teaching approach has impacted pre-service teachers as they move into the industry and the flow-on effect that it may have on school classrooms as graduate teachers enter the workforce. This further study could therefore explore the crucial link between tertiary sector teaching approaches, innovative pre-service teaching courses and the influences and pressures that underpin choices about teaching approaches in schools.

\section{References}

Australian Council for Educational Research. (2009). Australasian survey of student engagement. Melbourne: Author. Retrieved from http://www.acer.edu.au/ausse

Alber, S. M. (2011). A toolkit for action research. Lanham, MD: Rowan \& Littlefield.

American University of Beirut. (2010, April 29). New blended learning teaching approach enthusiastically received. News. Retrieved from https://www.aub.edu.lb/news/Pages/106523.aspx

Arbaugh, J. B., Bangert, A., \& Cleveland-Innes, M. (2010). Subject matter effects and the Community of Inquiry (CoI) framework: An exploratory study. Internet and Higher Education, 13, 37-44. doi:10.1016/j.iheduc.2009.10.006

Arnold, J., \& Jackson, I. (1996). The keys to successful co-teaching. Thought and Action, 12(2), 91-98. doi:10.1300/j016v20n01_11

Bauwens, J., \& Hourcade, J. J. (1997). Cooperative teaching: Pictures of possibilities. Intervention in School and Clinic, 33(2), 81-85. doi:10.1177/105345129703300202

Benjamin, J. (2000). The scholarship of teaching in teams: What does it look like in practice? Higher Education Research \& Development, 19(2), 191-204. doi:10.1080/072943600445646

Bess, J. L. (2000). Teaching alone, teaching together: Transforming the structure of teams for teaching. San Francisco, CA: Jossey-Bass.

Bondy, E., \& Ross, D. (1998). Teaching teams: Creating the context for faculty action research, Innovative Higher Education, 22(3), 231-49. doi:10.1023/a:1025191527703

Boulay, M. (2005). Teacher content and pedagogical learning in secondary team teaching settings (Doctoral dissertation). Boston University School of Education, Boston, MA. Retrieved from ProQuest database. (Accession No. 305033307)

Boyle, T., Bradley, C., Chalk, P., Jones, R., \& Pickard, P. (2003). Using blended learning to improve student success rates in learning to program. Journal of Educational Media, 28, 165-178. doi:10.1080/1358165032000153160

Clayton Christensen Institute. (2015). Introduction to blended learning - Khan Academy. Retrieved from https://www.khanacademy.org/partner-content/ssf-cci/sscc-intro-blended-learning

Davis, J. R. (1995). Interdisciplinary courses and team teaching: New arrangements for learning. Phoenix, AZ: American Council on Education/Oryx Press Series on Higher Education.

Department of Education and Early Childhood Development. (2012). Blended learning - A synthesis of research findings in Victorian Education 2006-2011. Melbourne: Author. Retrieved from http://www.education.vic.gov.au/Documents/about/research/blendedlearning.pdf

Donnison, S., Edwards, D., Itter, D., Martin, D., \& Yager, Z. (2009). Reflecting on improving our practice: Using collaboration as an approach to enhance first year transition in higher education. Australian Journal of Teacher Education, 34(3). doi:10.14221/ajte.2009v34n3.2

Edwards, D., \& McMillan, J. (2015). Completing university in Australia: A cohort analysis exploring equity group outcomes. Joining the Dots - Research Briefing Paper, 3(3), 1-12. Melbourne: Australian Council for Educational Research. Retrieved from https://www.acer.edu.au/files/Completion-of-Equity-Groups-JTD-RB-V3-N3-May-2015.pdf

Eisen, M. J. (2000). The many faces of team teaching and learning: An overview. In M.-J. Eisen \& E. J. Tisdell (Eds.), Team teaching and learning in adult education: New directions for adult and continuing education (No. 87) (pp. 5-14). San Francisco, CA: Jossey-Bass.

Eisen, M. J., \& Tisdell, E. J. (Eds,). (2000). Team teaching and learning in adult education: New directions for adult and continuing education (No. 87). San Francisco, CA: Jossey Bass. 
Farey, J. (1974). Openness and team teaching, Education 3-13. International Journal of Primary, Elementary and Early Years Education, 2(2), 94-96. doi:10.1080/03004277408558951

Francis, R., \& Shannon, S. (2013). Engaging with blended learning to improve students' learning outcomes. European Journal of Engineering Education, 38(4), 359-369. doi:10.1080/03043797.2013.766679

Freeman, J. (1969). Team teaching in Britain. London: Ward Lock.

Friend, M., \& Cook, L. (2007). Interaction: Collaboration skills for school professionals (5th ed.). Boston: Allyn \& Bacon.

Fuller, R., \& Bail, J. (2011). Team teaching in the online graduate learning environment: Collaborative instruction. International Journal of Information and Communication Technology Education, 7(4), 72-83. doi:10.4018/jicte.2011100107

Garrison, D. R., \& Kanuka, H. (2004). Blended learning: Uncovering its transformative potential in higher education. The Internet and Higher Education, 7(2), 95-105. doi:10.1016/j.iheduc.2004.02.001

Garrison, D. R., \& Vaughan, N. D. (2011). Blended learning in higher education: Framework, principles, and guidelines. San Francisco, CA: Wiley.

Gedik, N., Kiraz, E., \& Ozden, M. Y. (2013). Design of a blended learning environment: Considerations and implementation issues. Australasian Journal of Educational Technology, 29(1), 1-19. doi:10.14742/ajet.6

Geen, A. G. (1985). Team teaching in the secondary schools of England and Wales. Educational Review, 37(1), 29-38. doi:10.1080/0013191850370104

George, M. A., \& Davis-Wiley, P. (2000) Team teaching a graduate course: Case study: A clinical research course. College Teaching, 48 (2), 75-80. doi:10.1080/87567550009595818

Ginns, P., \& Ellis, R. A. (2009). Evaluating the quality of e-learning at the degree level in the student experience of blended learning. British Journal of Educational Technology, 40(4), 652-663. doi:10.1111/j.1467-8535.2008.00861.x

Haddon, E. (2011). Multiple teachers, multiple gains. British Journal of Music Education, 28(1), 68-95. doi: $10.1017 / \mathrm{s} 0265051710000422$

Hare, J. (2010, October 20). High university drop-out rates cost \$1.4bn. The Australian. Retrieved from http://www.theaustralian.com.au/higher-education/high-university-drop-out-rates-cost-14bn/storye6frgcjx-1225940860074

Hendricks, C. (2009). Improving schools through action research: A comprehensive guide for educators. Upper Saddle River, NJ: Pearson.

Hoic-Bozic, N., Mornar, V., \& Boticki, I. (2009). A blended learning approach to course design and implementation. IEEE Transactions on Education, 52(1), 19-30. doi:10.1109/te.2007.914945

Huang, R., \& Zhou, Y. (2005). Designing blended learning focused on knowledge category and learning activities. In C. J. Bonk \& C. R. Graham (Eds.), Handbook of blended learning: Global perspectives, local designs (pp. 296-310). San Francisco, CA: Pfeiffer Publishing.

Johnson, A. P. (2012). A short guide to action research (4th ed.) Upper Saddle River, NJ: Pearson.

Johnson, D. W., Johnson, R. T., \& Smith, K. A. (2000). Constructive controversy. Change, 32(1), $28-37$. doi: $10.1080 / 00091380009602706$

Knights, S., \& Sampson, J. (1995). Reflection in the context of team teaching. Studies in Continuing Education, 17(1 \& 2), 58-69. doi:10.1080/0158037950170106

Letterman, M., \& Dugan, K. (2004). Team teaching a cross-disciplinary honors course. College Teaching, 52(2), 76-79. doi:130.132.173.208

Lim, D. H., \& Yoon, S. W. (2008). Team learning and collaboration between online and blended learner groups. Performance Improvement Quarterly, 21(3), 59-72. doi:10.1002/piq.20031

Mansell, J. (2006). Team teaching in further education. Educational Research, 17(1), 19-26. chttp://dx.doi.org/10.1002/piq.20031

McCarthy, J. (2010). Blended learning environments: Using social networking sites to enhance the first year experience. Australasian Journal of Educational Technology, 26(6), 729-740. doi:10.14742/ajet.1039

McNiff, J. \& Whitehead, J. (2000). Action research in organisations. London: Routledge

Mills, G. E. (2003). Action Research: A guide for the teacher researcher (2nd ed.). Upper Saddle River, NJ: Merrill Prentice Hall.

Montgomery, A. P., Hayward, D. V., Dunn, W., Carbonaro, M., \& Amrhein, C. G. (2015). Blending for student engagement: Lessons learned for MOOCs and beyond. Australasian Journal of Educational Technology, 31(6), 657-670. doi:10.14742/ajet.1869 
Mortera-Gutiérrez, F. (2006). Faculty best practices using blended learning in e-learning and face-to-face instruction. International Journal on E-learning, 5, 313-337.

Newcombe, E. (2011, June). A work in progress: Refining the "blend" of face-to-face and online instruction. Paper presented at the World Conference on Educational Multimedia, Hypermedia and Telecommunications 2011, Lisbon, Portugal. Retrieved from http://www.editlib.org/p/38304

Noffke, S., \& Somekh, B. (Eds.) (2009). Handbook of educational action research. London: Sage.

Noffke, S., \& Somekh, B. (2011). Action research. In C. Noffke \& B. Somekh (Eds.), Theory and methods in social research (2nd ed.) (pp. 94-101). London: Sage.

Oblender, T. E. (2002). A hybrid course model: One solution to the high online drop-out rate. Learning \& Leading with Technology, 29(6), 42-46.

Osguthorpe, R. T., \& Graham, C. R. (2003). Blended learning environments: Definitions and directions. Quarterly Review of Distance Education, 4(3), 227-233.

Pektas, S. T., \& Gürel, M. (2014). Blended learning in design education: An analysis of students’ experiences within the disciplinary differences framework. Australasian Journal of Educational Technology, 30(1), 31-44. doi:10.14742/ajet.372

Pelton, R. P. (2010). Action research for teacher candidates: Using classroom data to enhance instruction. Lanham, MD: Rowman \& Littlefield.

Picciano, A. G. (2006). Blended learning: Implications for growth and access. Journal of Asynchronous Learning Networks, 10(3), 85-91. Retrieved from http://sloanconsortium.org/sites/default/files/v10n3_8picciano_0.pdf

Prensky, M. (2001). Digital natives, digital immigrants : Part 1. On the Horizon, 9(5), 1-6. doi:10.1108/10748120110424816

Robinson, B., \& Schaible, R. M. (1995). Collaborative teaching: Reaping the benefits, College Teaching, 43(2), 57-59. doi:10.1080/87567555.1995.9925515

Robinson, R. (2004). Selected faculty experiences in designing and teaching blended learning courses at Brigham Young University (Doctoral dissertation). The Graduate College at the University of Nebraska, Lincoln, Nebraska. Retrieved from ProQuest database. (Accession no. 305161447)

Rosenburg, M. J. (2006). Beyond e-learning: Approaches and technologies to enhance organizational knowledge, learning and performance. San Francisco, CA: Jossey-Bass/Pfeiffer.

Sagor, R. (2000). Guiding school improvement with action research. Alexandria, VA: Association for Supervision and Curriculum Development.

Shibley, I. A. (2006). Interdisciplinary team teaching: negotiating pedagogical differences. College Teaching, 54(3), 271-274. doi:10.3200/ctch.54.3.271-274

Sloan Consortium. (2007). Blending in: The extent and promise of blended education in the United States. Retrieved from http://olc.onlinelearningconsortium.org/publications/survey/blended06

Smith, B. L. (1994). Team-teaching methods. In K. W. Prichard \& R. McLaran Sawyer (Eds.), Handbook of college teaching: Theory and applications (pp. 127-138). Westport, CT: Greenwood Press.

So, H., \& Brush, T. (2008). Student perceptions of collaborative learning, social presence and satisfaction in a blended learning environment: Relationships and critical factors. Computers \& Education, 51, 318-336. doi:10.1016/j.compedu.2007.05.009

Spiliotopoulos, V. (2011). Towards a technology-enhanced university education. In A. Kitchenham (Ed.), Blended learning across disciplines: Models for implementation (pp. 1-16). Prince George: University of Northern British Columbia.

Stringer, E. (2008) Action research in education (2nd ed.). Upper Saddler River, NJ: Pearson/Merrill Prentice Hall.

Thorne, K. (2003). Blended learning: How to integrate online and traditional learning, London: Kogan Page.

Torrisi-Steele, G., \& Drew, S. (2013). The literature landscape of blended learning in higher education: The need for better understanding of academic blended practice. International Journal for Academic Development, 18(4), 371-383. doi:10.1080/1360144X.2013.786720

Turney, C., Robinson, D., Lee, M., \& Soutar, A. (2009). Using technology to direct learning in higher education. Active Learning in Higher Education, 10(1), 71-83. doi:10.1177/1469787408100196

United States Department of Education. (2009). Evaluation of evidence-based practices in online learning: A meta-analysis and review of online learning studies. Washington, DC: Office of Planning, Evaluation, and Policy Development.

University Experience Survey (UES) Consortium. (2015). 2014 University Experience Survey National Report. Retrieved from https://docs.education.gov.au/documents/2014-university-experience-survey$\underline{\text { national-report }}$ 
Vogler, K., \& Long, E. (2003). Team teaching two sections of the same undergraduate course: a case study. College Teaching, 51(4), 122-126. doi:10.1080/87567550309596426

Welch, M., \& Sheridan, S. M. (1996). Tele-educational consortium: Strategies for school-based and school-home partnerships. Salt Lake City: University of Utah.

White, C. S., Henley, J. A., \& Brabston, M. E. (1998). To team teach or not to team teach-that is the question: A faculty perspective. Marketing Education Review, 8(3), 13-23. doi:10.1080/10528008.1998.11488640

Winn, J. A., \& Messenheimer-Young, T. (1995). Team teaching at the university level: What we have learned. Teacher Education and Special Education, 18(4), 223-229. doi:10.1177/088840649501800402

$\mathrm{Xu}, \mathrm{D}$., \& Jaggars, S. S. (2011a). The effectiveness of distance education in Virginia's community colleges: Evidence from introductory college-level math and English courses. Educational Evaluation and Policy Analysis, 33(3), 360-377. doi:10.3102/0162373711413814

$\mathrm{Xu}, \mathrm{D}$. \& Jaggars, S. S. (2011b). Online and hybrid course enrollment and performance in Washington State Community and Technical Colleges (CCRC Working Paper No. 31). Retrieved from ERIC database. (ED517746)

York-Barr, J., Ghere, G. S., \& Sommerness, J. (2007). Collaborative teaching to increase ELL student learning. Journal of Education for Students Placed at Risk, 12(3), 301-335. doi:10.1080/10824660701601290

Corresponding author: R. Crawford, renee.crawford@monash,edu

Australasian Journal of Educational Technology (c) 2017.

Please cite as: Crawford, R., \& Jenkins, L. (2017). Blended learning and team teaching: Adapting pedagogy in response to the changing digital tertiary environment. Australasian Journal of Educational Technology, 33(2), 51-72. https://doi.org/10.14742/ajet.2924 